\title{
CONSTRAINTS ON THE USAGE OF VERBAL NEGATION IN BRAZILIAN PORTUGUESE - EVIDENCE FROM A SPOKEN CORPUS
}

\author{
Restricciones en el uso de la negación verbal en el portugués brasileiro - \\ evidencia desde un corpus de habla
}

\section{Luis Filipe Lima e Silva*}

Heliana Mello**

\begin{abstract}
RESUMEN
El sistema de negación verbal del Portugués Brasileño (BP) presenta tres formas, la pre-verbal, la doble y la postverbal, como puede ser visto, respectivamente, en los siguientes ejemplos: *MIC: [91] mas / Michael / eu não falo nesse sentido // (ii) *DOM: [101] cês nũ lêem isso mais não // (iii) *RUT: [220] participa não / minha filha //.El propósito de esta investigación es averiguar si hay algún tipo de restricción prosódico-informacional en el uso de las tres formas de negación verbal del BP a través del corpus del habla espontánea C-ORALBRASIL (Raso \& Mello, 2012). A través del análisis de los datos recogidos del corpus C-ORAL-BRASIL, proponemos que las formas doble y postverbal de la negación están restringidas a ocurrir únicamente en unidades ilocucionarias (COM, CMM, COB), al paso que la forma pre-verbal presenta distribución libre, pudiendo ocurrir tanto en unidades ilocucionarias como en otras unidades textuales. Eso indicaría que las formas no canónicas requerirían la fuerza ilocucionaria para que puedan ser plenamente realizadas.

Palabras clave: negación verbal; portugués brasileño; corpus; prosódia; pragmática.
\end{abstract}

\begin{abstract}
The verbal negation system of Brazilian Portuguese (BP) presents three forms: preverbal, double and postverbal negation, as can be seen in following examples: *MIC: [91] mas / Michael / eu não falo nesse sentido // (ii) *DOM: [101] cês nũ lêem isso mais não // (iii) *RUT: [220] participa não / minha filha //. The goal of this paper is to investigate whether there is any kind of prosodic-informational restriction to the distribution and use of the above mentioned negation forms in BP through the spontaneous speech corpus C-ORAL-BRASIL BRASIL (Raso \& Mello, 2012). Through the analysis of data from C-ORAL-BRASIL, we propose that double and postverbal negation can only occur in illocutionary information units (COM, CMM, COB); whereas preverbal negation has free distribution, occurring in both illocutionary and non-illocutionary textual units. This indicates that non-canonical negation forms depend on illocutionary force in order to be fully realized. Key Words: verbal negation; Brazilian Portuguese; corpus; prosody, pragmatics.
\end{abstract}




\section{Introduction}

Verbal negation is widely studied under different theoretical and methodological frameworks. Semantic, pragmatic and prosodic investigations, for example, reflect the importance of studying negation in contemporary linguistics (cf. Sousa, 2012; Schwenter, 2005; Armstrong, Bergmann, Tamati, 2008). Verbal negation, typologically considered a linguistic universal, is characterized by being a grammatically complex structure, i.e., a negated form is more complex than an affirmative form; therefore, a negative declarative sentence, for example, would be more complex both from a formal point of view (lexico-morphological) as well as from a semantic point of view in relation to an affirmative declarative sentence (cf. Miestamo, 2005), as discussed for examples (1) and (2) below:

(1) O avião decolou às 17:30 hs.

The plane took off at 5:30 pm.

(2) O avião não decolou às 17:30 hs.

The plane didn't take off at 5:30 pm.

What can be noticed through the pair of sentences above is that (2) would be morphologically more complex than (1) because there is one additional word, namely the adverb não. Semantically, (2) would also be more complex since (1) expresses a proposition (p) and (2) denies this proposition $(\sim p)$. According to Miestamo (2005), the function of verbal negation is to modify the sentence that displays a proposition $\mathrm{p}$, such that the modified sentence expresses its opposite truth value, i.e., $\sim$ p.

Brazilian Portuguese (BP) has three forms of verbal negation, namely preverbal [ $\mathrm{Neg}$ $\mathrm{V}$ ], double [Neg V Neg] and postverbal [V Neg], as seen in the examples below:

(3) bfamcv01:

*LUI: [7] < com certeza es nũ vão participar $/=\mathbf{C O M}=$ uai $>/ /=\mathrm{PHA}=$

They will not participate, for sure

(4) bfamcv02:

*RUT: [91] eu nũ quero não $/ /=\mathbf{C O M}=$

I don't want (it)
(5) bfamcv02:

*JAE: [12] <ganhou não $>/ /=\mathbf{C O M}=$

(He) didn't win

The aim of this paper is to discuss the distribution of these three forms in a spoken corpus in the framework a pragmatically oriented theory, the Language into Act Theory (LAcT). The paper is organized as follows: section 1 introduces the theory, section 2 shows the relation of prosody and pragmatics, i.e. the mapping between tonal units (prosody) and informational units (pragmatics), section 3 introduces the corpus employed in the research, section 4 features the results found and, finally, section 5 brings some final remarks.

\section{Action through speech: The Language into Act Theory}

The Language into Act Theory [LAcT] (Cresti, 2000; Moneglia \& Raso, 2014) is a corpus-driven theory of language. This means that this theory follows an inductive research criterion, namely, the corpus is the empirical source from which regularities subsequently are systematized into theoretical assumptions. LAcT studies spontaneous speech and is therefore based on spontaneous speech corpora. Spontaneous speech can be characterized as speech that is performed at the same time that it is uttered (Nencioni, 1983). Therefore, the corpora compilation process eliminates situations in which speech cannot be deemed spontaneous, as for example in plays, soap operas, movies, read speeches, etc. All these exemplified situations share a common characteristic, that is, the executed speech originates from a written text previously prepared. In these situations the linguistic production is not spontaneous because speech is not performed at the same time that it is planned.

Due to the nature of spontaneous speech, its transcription process requires specific criteria that portray its properties, avoiding skewing brought about by formal written text features. The C-ORAL-BRASIL transcription 
guidelines capture in-progress lexicalization and grammaticalization phenomena, besides morphosyntactic structures that are typical of spontaneous speech. Furthermore, the transcription adopts semiorthographic criteria to fully encompass spoken phenomena on the one hand, and to keep readability on the other (cf. Raso; Mello, 2009, Mello et al, 2012). In addition to the parameters just mentioned, the transcription must accurately represent defining prosodic features that interface with information structure while, at the same time, respecting the diamesic differences between speech and writing (cf. Raso, 2013). Therefore, it is necessary to adopt a reference unit for spontaneous speech, that is, a formal construct that will be used to indicate a meaningful unit for the study of speech. Despite the fact that the speaker's turn is considered to be such a unit in some approaches, the turn is set based on sequential spoken material produced by each participant in a speech event. The main problem in defining a turn refers to delimiting when it starts and ends. This is particularly difficult given that commonly there is overlapping speech. LAcT, on the other hand, defines such a reference unit taking into account the pragmatic-discursive level which is anchored on prosody, as will be shown later.

According to LAcT the study of speech requires the identification of a linguistic unit that matches the communicative activity that takes place in a given speech event. Departing from the Theory of Speech Acts (Austin, 1962), LAcT proposes that the communicative activity unit is the speech act. Spontaneous speech features actions carried out through speech acts. Thus, the identification of the reference unit of spontaneous speech depends upon the delimitation of a pragmatically autonomous sequence in the continuous flux of speech. The reference unit of speech is thereby established as the utterance, defined as the smallest linguistic unit that has both pragmatic autonomy and interpretability in isolation. It thus binds the field of action to a linguistic unit, that is, the act of speaking to the utterance. In this way, every utterance carries a speech act. It should be noticed that the definition of utterance in LAcT is pragmatic-discursive in its nature and not semantic-syntactic; this eliminates the necessity for the presence of a verb in speech reference unit such as required by a proposition/sentence.

As mentioned above, the utterance always corresponds to a speech act. According to Austin (1962), the speech act is performed simultaneously through three acts: the locutionary, the illocutionary and perlocutionary acts. The locutionary act corresponds to the pure action of speaking or the linguistic production. The illocutionary act corresponds to the action that is performed through speech, that is, an order, a request, an offer, a refusal, a greeting, etc. The perlocutionary act corresponds to the effect caused on the interlocutor in the form of further action. For LAcT, the simultaneous completion of locutionary and illocutionary acts is the basis for the illocutive principle, i.e. the two-way relationship between an utterance and a speech act. Thus, an utterance asserts one, and only one, action. There are no morphosyntactic restrictions in the realization of an utterance. Examples (6) and (7) are considered utterances, because they have pragmatic autonomy and interpretability in isolation (which can only be verified through listening to their sound files):

(6) bfamcv01:

*LUI: [10] <agora> manda uma barrinha $<$ minha $>/ /=\mathrm{COM}=1$

Now, give me one of my bars

(7) bfamcv01:

*EVN: [38] uhn $/ /=\mathrm{COM}=$

$\mathrm{Hmm}$ ?

As can be seen, (6) is an utterance that carries a proposition and is coded through a sentence; however (7) is a fully interpretable utterance that is coded through an interjection and does not have a propositional nor a sentential structure.

Every utterance carries an illocutionary force, which enables it to perform an illocution; the relationship between an utterance and an illocution is equated by the production of locutive material- or linguistic content - concurrent with the completion of a speech act. Each illocution 
features its own prosodic features that distinguish it from other illocutions, i.e., an illocution has its own conventional intonation profile. Therefore, all order illocutions, for example, present a similar intonation profile, although their locutive contents may be very dissimilar. This means that an illocution of order can be performed independently of the lexical items it contains; therefore, a verb in the imperative form is not necessary for an order to be executed in linguistic terms. This enables the identification of an illocution through its intonation profile or, in general terms, its prosodic features. Prosody is then responsible for mediating the relationship between the linguistic domain, represented by utterances, and the pragmatic domain, represented by speech acts. Moreover, it is through prosody that speech can be segmented into utterances and in their own internal units.

In order to identify illocutions, the most relevant prosodic parameter to be taken into account is intonation. According to LAcT, there are four basic functions performed by intonation in the context of the pragmatic study of speech which are:

a. segmentation of each utterance in the continuous flow of speech;

b. segmentation of internal units of an utterance (if there are any);

c. assignment of a specific illocution to every utterance;

d. assignment of a value or an information function to each of the internal units of the utterance.

Intonation will serve its functions in the identification of an utterance out of a continuous flux of speech, as well as its internal units, as shown in examples (8)-(10) below. In (8), the flux of speech is transcribed and without intonation it is not possible to know whether it corresponds to one or more utterances.

(8) bfamcv01:

*EVN: [19] No' o Galáticos é mesmo todo mundo é $<$ babaca $>$

Really everyone in Galaticos is an asshole
Through intonation, it is possible to identify that the whole string corresponds to one utterance and its rightward boundary is marked by two slashes, indicating that there is a perceived terminal break at that point:

(9) bfamcv01:

*EVN: [19] No’ o Galáticos é mesmo todo mundo é $<$ babaca $>/ /$

Really everyone in Galaticos is an asshole

In (10), through intonation, the utterance three internal units are identified and signaled through single slashes that correspond to perceived non-terminal breaks:

(10) bfamcv01:

*EVN: [19] No' / o Galáticos é mesmo / todo mundo é babaca //

Really, everyone in Galaticos is an asshole

It is also through intonation that the informational values of the utterance internal units will be identified as in (11), which will lead, additionally, to the assignment of an illocutionary value carried by the illocutionary unit $\mathrm{COM}^{2}$ :

(11) bfamcv01:

*EVN: [19] No' $/=\mathrm{EXP}=$ o Galáticos é mesmo $/=\mathrm{INT}=$ todo mundo é $<$ babaca $>/ /=\mathrm{COM}=$

The task of identifying an utterance and segmenting it into its internal units (if any) is done through the perception of prosodic cues. Such cues can be perceived as prosodic breaks. A prosodic break may have conclusive value or not. If it has conclusive value, it is called a terminal prosodic break; if it does not carry a conclusive value it is called a non-terminal prosodic break. Breaks perceived as terminal indicate the final, rightward boundary of an utterance. In the examples above (8-11), double slashes mark a terminal break or the end of the utterance. The breaks perceived as non-terminal indicate utterance internal units. These are marked with single slashes. A complex utterance will be organized through internal units, as in (11). On the other hand, a simple utterance will be made up of a single unit as in (12): 
(12) bfamcv01:

*LEO: [1] o Juninho $<$ foi $>/ /=\mathrm{COM}=$ Juninho went

Prosodic breaks in an utterance have two main dimensions: a prosodic dimension as well as a pragmatic-informational one. Each prosodic break perceived either as terminal or non-terminal delimits a tonal unit in the prosodic level of the utterance. In the pragmatic level, a tonal unit corresponds to an informational unit. Every utterance has a prosodic break perceived as terminal, that is, every utterance has at least one tonal unit. In the pragmatic-informational level this necessary unit is called Comment (COM). The COM unit is responsible for carrying the illocutionary force of the utterance.

Tonal units have different prosodic profiles. The prosodic framework in which LAct is based derives from the research by the IPO study group (Institute of Perception Research, Eindhoven), which sought to build a grammar of intonation through experimental methods involving perception. IPO's findings revealed that an utterance is produced by many pitch movements ('t Hart; Collier; Cohen, 1990). However, only the movements intentionally produced are perceived by speakers of a language. There are several involuntary movements due to the human physiology, which are not perceived by the speakers. The concept of pitch contour is related to relevant movements of an utterance, that is, the only movements intentionally produced and used in the interpretation of the utterance. There are settings of movements that may be listed distributionally in three types of pitch contours called prosodic profiles:

a. Root: mandatory settings and nonrecursive. A contour should have only one root.

b. Prefix: optional settings, some recursive. Always precedes a root or other prefixes.

c. Suffix: Optional and non-recursive settings. Always follows a root.

For LAcT, the perception of intonation plays a key role as it is through it that a listener identifies the relevant movements made intentionally by a speaker. According to the Information Standardization Hypothesis (Cresti; Moneglia, 2010), prosodic profiles attribute informational values to tonal units. Thus, the root prosodic profile is what plays the central role in the utterance; it is the autonomous prosodic unit par excellence because it carries the illocution. Changes in syllabic alignment and length ensure that there are different illocutionary forms of the same speech act in the prosodic root profile (Firenzuoli, 2003). This means that the root unit is pragmatically autonomous and configures various types of illocutions. Moreover, the root unit is informationally linked to the COM. Thus, in pragmatic-informational terms, in order for an utterance to be accomplished, the only necessary element is the COM unit.

\section{Prosody meets pragmatics: informational units}

According to LAcT there is isomorphism between tonal units and informational units as they belong to different dimensions: the former belongs to the prosodic dimension of speech, while the latter belongs to the pragmatic-informational dimension. Prosody distributionally outlines tonal units, as seen in section 1 , besides fulfilling the role of assigning a pragmatic-informational value to them. Informational units are identified through the following three criteria:

a. Functional: what pragmatic function is performed by an informational unit;

b. Intonational: What are the prosodic features of a given unit ;

c. Distributional: What the distribution of a given unit is in relation to the comment unit.

Informational units belong to two separate groups which fulfill either textual or dialogical functions. Textual function units compose the text of the utterance, while dialogical units are intended to address the listener in order to regulate the on-going interaction. Textual units 
are: Comment (COM), Multiple Comment (CMM), Bound Comment (COB), Appendix of Comment (APC), Topic (TOP), Appendix of Topic (APT), Locutive Introducer (INT) and Parenthesis (PAR). Dialogic units are: Allocutive (ALL), Conative (CNT), Discourse Connector (DCT), Expressive (EXP), Incipit
(INP) and Phatic (PHA). Textual units will be presented in table 1 below as they are the ones that are involved in the codification of verbal negation in Brazilian Portuguese. For fuller discussion and description of information units according to LAcT, see Moneglia \& Raso (2014).

TABLE 1.

LAcT tagset and definition of textual information units (adapted from MONEGLIA \& RASO, 2014)

\begin{tabular}{|c|c|c|}
\hline Textual unit & Tag & Definition \\
\hline Comment & $\mathrm{COM}$ & $\begin{array}{l}\text { Accomplishes the illocutionary force } \\
\text { of the utterance. It is necessary and } \\
\text { sufficient for the performance of the } \\
\text { utterance. }\end{array}$ \\
\hline Topic & TOP & $\begin{array}{l}\text { Identifies the domain of application } \\
\text { for the illocutionary act expressed by } \\
\text { the comment, allowing a cognitive } \\
\text { reference to the speech act. It allows } \\
\text { the utterance to be displaced from the } \\
\text { context (linguistic and non-linguistic). }\end{array}$ \\
\hline Appendix of Comment & APC & $\begin{array}{l}\text { Integrates the text of the comment and } \\
\text { concludes the utterance, marking an } \\
\text { agreement with the addressee. }\end{array}$ \\
\hline Appendix of Topic & APT & $\begin{array}{l}\text { Gives a delayed integration of the } \\
\text { information given in the topic. }\end{array}$ \\
\hline Parenthesis & PAR & $\begin{array}{l}\text { Inserts information into the utterance } \\
\text { with a meta-linguistic value, having } \\
\text { backward or forward scope. }\end{array}$ \\
\hline Locutive Introducer & INT & $\begin{array}{l}\text { Expresses the evidence status of the } \\
\text { subsequent locative space (simple } \\
\text { or patterned) marking a shift in the } \\
\text { coordinates for its interpretation. }\end{array}$ \\
\hline Multiple Comment & $\mathrm{CMM}$ & $\begin{array}{l}\text { Constitutes a chain of comments } \\
\text { which form an illocutionary pattern } \\
\text { i.e. an action model which allows the } \\
\text { linking of at least two illocutionary } \\
\text { acts, for the performance of one } \\
\text { conventional rhetoric effect. }\end{array}$ \\
\hline Bound Comment & $\mathrm{COB}$ & $\begin{array}{l}\text { A sequence of comments, which are } \\
\text { produced by progressive adjunctions } \\
\text { which follow the flow of thought. } \\
\text { It forms a Stanza out of any } \\
\text { informational model. }\end{array}$ \\
\hline
\end{tabular}




\section{A spontaneous speech corpus: The C-ORAL-BRASIL project}

C-ORAL-BRASIL (RASO \& MELLO, 2012) is a branch of the C-ORAL-ROM project (Cresti \& Moneglia, 2005), which is coordinated by professors Tommaso Raso and Heliana Mello, at LEEL (Laboratory for Empirical and Experimental Linguistics) at the Universidade Federal de Minas Gerais, Brazil. The C-ORALBRASIL corpus is a spontaneous speech corpus of Brazilian Portuguese, designed to be comparable to the Romance language corpora in the C-ORAL-ROM project (cf. CRESTI; MONEGLIA, 2005). The informal part of the C-ORAL-BRASIL was published in 2012, and its formal part is in its final compilation stages.

The informal part of the C-ORALBRASIL comprises 208,130 words, distributed over 139 texts, totaling 21:08:52 hs of speech recording. The sound files are in WAV format, the transcripts in RTF comply with CHILDESCLAN parameters (Mac Whinney, 2000), alignment files are in XML format and metadata in txt. The recordings were made with PDD60 Marantz digital recorders and Sennheiser Evolution EW100 G2 wireless kits, made up of lapel microphones, transmitters and receivers. Some recordings were made with Sennheiser MD 421 omnidirectional microphones and a Xenyx 1222 mixer. The morphosyntactic annotation was carried through the PALAVRAS parser (Bick, 2000).
The C-ORAL-BRASIL corpus is divided in family and public-private interactions, with conversations, dialogues and monologues. The speech situations present high variability and try to portray as much of actual interactional situations as possible, being represented by actional contexts such as a conversation taking place as participants play football, a dialogue between a builder and an engineer in a construction site, a dialogue between shoppers at a supermarket, etc. Each text of the corpus consists of an audio file, two transcripts in RTF and txt, two text-sound alignment files in XML and wp2 formats, a txt file containing the participants' and recording metadata. On average, each text of the corpus contains 1,500 words.

\section{Prosodic-informational constraint on verbal negation in Brazilian Portuguese}

As indicated in the Introduction of this paper, spoken Brazilian Portuguese has three types of verbal negation: pre-verbal negation (Neg V), double verbal negation (Neg V $\mathrm{Neg}$ ) and post-verbal negation (V Neg). Neg is filled by the adverbial form não which in both pre-verbal negation as well as in the preverbal position in double negation can also be realized as $n \hat{u}$.

Through the extraction of all occurrences of verbal negation in the C-ORAL-BRASIL, we reached the distribution numbers by type presented in table 2 below:

TABLE 2.

Distribution of the verbal negation in the C-ORAL-BRASIL corpus

\begin{tabular}{lllll}
\hline Negation & Neg V & Neg V Neg & V Neg & Total \\
\hline Total & 2,262 & 704 & 148 & 3,114 \\
\hline
\end{tabular}


The 3,114 occurrences of verbal negation found in the C-ORAL-BRASIL corpus were analyzed taking into account their distribution across information units. Having LAcT informational units in mind, we reached the following findings: pre-verbal negation has free distribution within the scope of textual informational units, whereas double negation and post-verbal negation can only occur in illocutionary units, that is, units carrying a speech act, namely COM, CMM and COB. Informational units were both extracted from the annotated sample of the corpus available through the DB-IPIC platform ${ }^{3}$ as well as recognized through the perception af native speakers. Examples extracted for the corpus are presented below, illustrating the distribution of verbal negation in informational units. Examples (13)-(20) illustrate the diversity of textual information units ranging from non-illocutinary to locutionary units:

(13) bfamcv03 - Neg V in Topic (TOP) unit *TON: [41] é $/=\mathrm{EXP}=$ se o meu pai também nũ tivesse morrido $/=\mathbf{T O P}=$ tava vivo $/=\mathrm{COB}=$ tava com noventa-e-seis ano $/ /=\mathrm{COM}=$

If my father hadn't died, if he was alive, he would be ninety sixf

(14) bfamcv03 - Neg V in Parenthesis (PAR) unit *TON: [243] <dá licença um> pouquinho $/=\mathrm{COB}=$ enquanto cê $\boldsymbol{n u}$ tá jogando $/=\mathbf{P A R}=$ que cê $[/ 1]=S C A=$ ninguém güenta esse cu seu não $/ /=\mathrm{COM}=$

Excuse me a little, while you are not playing, because you, nobody can handle this arse of yours

(15) bfamcv04 - Neg V in Locutive Introducer (INT) unit

*BRU: [175] <se for $>/=\mathrm{SCA}=$ um passarinho $/=\mathrm{TOP}=$ cê $\boldsymbol{n} \tilde{\boldsymbol{u}}$ pode fazer $/=\mathbf{I N T}=\mathrm{hhh} / /=\mathrm{COM}=$

If it is a bird you can't make (noise)

(16) bfamd104 - Neg V in Appedix of Comment (APC) unit

*SIL [16]: pode ser o creme $/=\mathrm{COM}=$ que $\boldsymbol{n} \tilde{u}$ deu certo com ele $/ /=\mathbf{A P C}=$
It might be the cream that did not work well for it

(17) bfamcv01 - Neg V in Multiple Comment (CMM) unit

*EVN: [50] ô $/=\mathrm{EXP}=$ mas tem outros lugares /=CMM= o negócio é que a gente não procurou $/ /=\mathbf{C M M}=$

Hey, but there are other places, the truth is we have not looked

(18) bfammn02 - Neg $\mathbf{V}$ in Bound Comment (COB) unit

*DFL: [57] e ele então nũ teve $/=\mathbf{C O B}=$ uma escola $/ /=\mathrm{COM}=$

And he then didn't attend a school

(19) bfamdl14 - Neg V in Appendix of Topic (APT) unit

*CAR: [213] ela dá aquela raspadinha de seis números / cinco número / ou seja se cê nũ / destacar $/=\mathrm{TOP}=e$ não conseguir ganhar $o$ prêmio eles te dão $/=\mathbf{A P T}=$ acho que cem reais $/$ $<$ uma coisa assim> //

She provides that lottery card with six numbers, five numbers, that is, if you can't make it and can't get the prize they give you about a hundred reais, something like that

(20) bfamcv01 - Neg V in Comment (COM) unit *LUI: [7] <com certeza es nũ vão participar $/=\mathbf{C O M}=$ uai $>/ /=\mathrm{PHA}=$

They will not participate for sure

As can be appreciated in the examples from (13) to (20) above, pre-verbal negation has free distribution with regard to textual informational units; therefore, it can occur in Comment (COM), Appendix of Comment (APC), Multiple Comment (CMM), Bound Comment (COB), Topic (TOP), Appendix of Topic (TOP) Locutive Introducer (INT) and Parenthesis (PAR).

Unlike pre-verbal negation, the less frequent verbal negation forms, i.e., double and post-verbal negation, have their occurrence constrained to illocutionary units: COM, CMM or $\mathrm{COB}$ as shown below in examples (21) to (30): 
(21) bfamcv01 - Neg V Neg in Comment (COM) unit

*LUI: [168] <pelo menos o José Mourinho nũ tem desses escrotos $\boldsymbol{n} \tilde{\boldsymbol{a}} \boldsymbol{o}>/ /=\boldsymbol{C O M}=$

At least José Mourinho doesn't have this kind of asshole

(22) bfamcv02 - Neg V Neg in Comment (COM) unit

*RUT: [91] eu nũ quero não $/ /=\mathbf{C O M}=$

I don't want (it)

(23) bfamcv02 - Neg V Neg in Multiple Comment (CMM) unit

*RUT: [382] não $/=\mathrm{CMM}=$ nũ é encontro no seu Antônio de $<$ Assis $>$ nã o $/ /=\mathbf{C M M}=$

$\mathrm{No}$, it is not a get together at Mr Antônio de Assis'

(24) bfamcv02 - Neg V Neg in Multiple Comment (CMM) unit

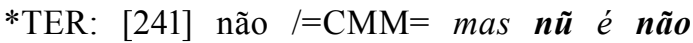
$/=\mathbf{C M M}=\& \mathrm{Ru}[/ 1] /=\mathrm{EMP}=\mathrm{Jael} / /=\mathrm{ALL}=$

No, but it is not (that), Jael

(25) bfammn01 - Neg V Neg in Bound Comment (COB) unit

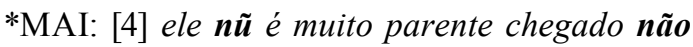
$/=\mathrm{COB}=$ mas $\& \mathrm{t}[/ 1] /=\mathrm{SCA}=$ deve ser $/$ primo $[/ 1]$ $/=\mathrm{EMP}=$ primo quarto $/=\mathrm{COM}=$ por aí $/=\mathrm{PAR}=$ deve ser $/ /=\mathrm{APC}=$

$\mathrm{He}$ is not a close relative, but he should be a cousin, forth removed, something like that

(26) bfammn01 - Neg V Neg in Bound Comment (COB) unit

*MAI: [21] n' é matinha igual essas capoeirinha

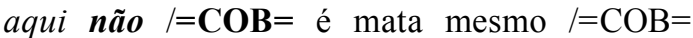
de $l=\mathrm{SCA}=$ madeira $/=\mathrm{SCA}=$ da grossura que $/=\mathrm{SCA}=$ quatro homem nũ abarca um pau $/ /=\mathrm{COM}=$

It is not some little bushes like these; it is really woods, as thick as four men can't embrace it

(27) bfamcv01 - V Neg in Comment (COM) unit

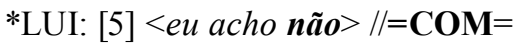
I don't think so
(28) bfamcv02 - V Neg in Comment (COM) unit

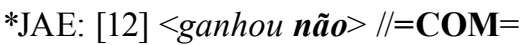

(He) din't win it

(29) bfamcv01 - V Neg in Multiple Comment (CMM) unit

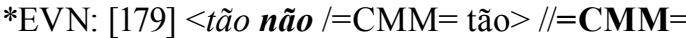
They are not, are they?

(30) bfamm03 - V Neg in Multiple Comment (CMM) unit

*ALO: [42] aí ea falou /=INT= não /=CMM r= vou lá não $/ /=\mathrm{CMM} \mathrm{r}=$

Then she said: no, I am not going there

(31) bfamcv03 - V Neg in Bound Comment (COB) unit

*CEL: [263] hhh mata não $/=\mathbf{C O B}=$ depois cê joga esse dois na frente dela $/ /=\mathrm{COM}=$

Don't kill (it); later you can place these two in front of it

(32) bfammn10 - V Neg in Bound Comment (COB) unit

*CEL: [14] sei $\boldsymbol{n} \tilde{a} \boldsymbol{o} /=\mathbf{C O B}=$ começar do começo / é bom //

I don't know, to start over is nice

After the analysis of all occurrences of verbal negation in the data examined, three exceptional tokens in which double negation occurs in a non-illocutionary unit, the Parenthesis unit, were found as will be shown through examples (33)-(35) below:

(33) bfammn04 - Neg V Neg in Parenthesis (PAR) unit

*REG: [113] eu tô aqui em casa / o Haroldo ainda nũ chegou nãa $/=\mathbf{P A R} \mathbf{r}=$ eu tô sentindo assim uma dorzinha na barriga / sior acha que já é algum sinal //

I am here at home, Haroldo hasn't arrived yet, I am feeling a little belly pain, do you think this is a sign?

(34) bfamn33 - Neg V Neg in Parenthesis (PAR) unit 
*ADR: [85] aí ele pegou lá / de repente tava a Madonna / ela nũ tava na capa dessa revista não /=PAR= ele viu falou assim / oh //

Then he grabbed it, all of a sudden it was Madonna, she wasn't on this magazine cover, he saw it and said "oh"

(35) bpubmn02 - Neg V Neg in Parenthesis (PAR) unit

*ANL: [51] e quando a gente tem implantado dentro da gente / o egoísmo / nũ quer dizer que eu nũ sou egoísta não /=PAR= sou / \&t [/1] ainda eu sou / infelizmente / mas / a gente tem que ter abertura / e \&n [/1] quando aparecer uma situação / na mão da gente / a gente tar aberto pa saber o que que é isso //

And when we have selfishness installed into ourselves, it doesn't mean I am not selfish, I am, unfortunately I still am, but we have to have openness, so that when a situation presents to us, we are open to know what this means.

The Parenthesis unit is treated differently than in LAcT by some authors ${ }^{4}$, in as far as it is seen as an autonomous unit. Given the low frequency of these occurrences, overall they do not challenge our analytical proposal, although they certainly require close examination and further study. An observation that should be noted regarding the specific nature of these three tokens is that they occur in monologues. Thus, it is necessary to investigate why the monologic textual typology licenses the use of double negation in PAR unit in order to fully understand the illocutionary and informational variables that might be involved. Additional particularities of these three occurrences are: one takes place in reported speech (33), another has a very high speech rate (34) and the last one a low speech rate (35). These details might be relevant to future investigation into the nature of Parenthesis as far as its illocutionary characterization might be, as well as its prosodic profiles in monologues.

Summarizing the results found in our research, table 3 below indicates the information units in which the three types of verbal negation can occur in Brazilian Portuguese:

TABLE 3.

Informational distribution of verbal negation in Brazilian Portuguese

\begin{tabular}{llll}
\hline & Neg V & Neg V Neg & V Neg \\
\hline Informational units & COM, APC, & COM, CMM, & COM, CMM, \\
& CMM, COB, & COB, PAR (only & COB \\
& TOP, APT, INT, & 3 occurences & \\
PAR & & \\
\hline
\end{tabular}

As can be noticed, pre-verbal negation has no prosodic-informational restrictions with regard to textual information units, whereas double and post-verbal negation can only occur in illocutionary units, except for the three cases of double negation which occur in Parenthesis unit in three monologic texts. What can be inferred from the results found is the fact that $\mathrm{Neg} \mathrm{V} \mathrm{Neg}$ and $\mathrm{V}$ Neg require Illocutionary force in order to be performed, whereas Neg $\mathrm{V}$ only requires a textual unit regardless of its illocutionary nature to occur; therefore it can be found in TOP, INT, PAR, APT or APC, as COM, $\mathrm{CMM}$ and $\mathrm{COB}$ units. Illocutionary units are autonomous from a prosodic-pragmatic point of view because they carry illocutionary force and convey illocutions. The restriction, therefore, found in the use of verbal negation in BP seems 
to be that non-canonical forms must necessarily be conveyed through an illocutionary unit. Why illocutionary force seems to be the core factor that restricts the use of non-canonical forms of verbal negation in BP needs further investigation to be fully understood.

\section{Final remarks}

In this paper we showed that verbal negation in Brazilian Portuguese has its occurrence constrained to a set of prosodic-informational environments. Preverbal negation - the canonic negation form - has free distribution across textual informational units. Postverbal negation occurs only in illocutionary units. Double negation occurs mostly in illocutionary units, but also can exceptionally occur in Parenthesis which is not an illocutionary informational unit. This could indicate that double negation might be undergoing a grammaticalization process, in which the environments for its production are being expanded. Some questions for future research to be pursued relate to the identification of illocutions types correlated with the occurrence of verbal negation in BP, the syntactic environments in which the three forms of verbal negation occur and to what extent the two previous questions influence utterance informational patterning.

\section{Notas}

1. The examples of utterances taken from the C-ORAL-BRASIL corpus follow a convention. The acronym "bfamcv01" informs the language $(\mathrm{b}=$ Brazilian Portuguese), the context (fam = familiar/ private, pub $=$ public $)$, the interactional type $(\mathrm{cv}$ = conversation, $\mathrm{dl}=$ dialogue, $\mathrm{mn}=$ monologue) and the text number. After the asterisk there are the initials of speakers, followed by a number in brackets, indicating the number of the utterance. The angled brackets indicate overlapping speech. Simple slashes indicate prosodic non-terminal breaks and double slashes indicate terminal prosodic breaks. Annotations after the prosodic breaks indicate the acronym for informational units. This will be dealt with in the section 2 .
2. Informational units will be discussed in section 2 .

3. CF. DB-IPIC at http://lablita.dit.unifi.it/app/dbipic/

4. Tommaso Raso (personal communication).

\section{References}

Armstrong, Meghan; Bergmann, Anouschka; Tamati, Terrin. (2008). The Prosody of Negation in Brazilian Portuguese. In: Proceedings of Speech Prosody, Campinas, Brasil.

Austin, John. (1962). How to do Things with Words. Oxford: OUP.

Bick, Eckhard. (2000). The Parsing System Palavras: Automatic Grammatical Analysis of Portuguese in a Constraint Grammar Framework. Aarhus: Aarhus University Press.

Cresti, Emanuela. (2000). Corpus di Italiano parlato. Firenze: Accademia della Crusca.

Cresti, Emanuela \& Moneglia, Massimo. (eds). (2005). C-ORAL-ROM: integrated reference corpora for spoken romance languages. Amsterdam/Philadelphia: John Benjamins.

Cresti, Emanuela \& Moneglia, Massimo. (2010). Informational patterning theory and the corpus-based description of spoken language: The compositionality issue in the topic-comment pattern. In: Moneglia, Massimo \& Panunzi, Alessandro (eds.). Bootstrapping Information from Corpora in a Cross-Linguistic Perspective. Firenze: Firenze University Press. p. 13-45.

Firenzuoli, Valentina. (2003). Le forme intonative di valore illocutivo dell'italiano parlato. (PhD Thesis). Firenze: Universita degli Studi di Firenze. 
Mac Whinney, Brian. (2000). The Childes project: tools for analyzing talk. Mahwah, NJ: Lawrence Erlbaum, 2 vols.

Mello, Heliana; Raso, Tommaso; Mitmann, Maryualê.; Vale, Heloísa; Côrtes, Priscila. (2012). Transcrição e segmentação prosódica do corpus C-ORAL-BRASIL: critérios de implementação e validação. In: Raso, Tommaso \& Mello, Heliana. (Orgs.). C-ORAL-BRASIL I: Corpus de referência do português brasileiro falado informal. Belo Horizonte: Editora UFMG. p. 125-176.

Miestamo, Matti. (2005). Standard negation: The negation of declarative verbal main clauses in a typological perspective. Berlin/New York: Mouton de Gruyter.

Moneglia, Massimo \& Raso, Tommaso. (2014). Notes on Language into Act Theory (L-AcT). In: Raso, Tommaso \& Mello, Heliana. (eds.). Spoken Corpora and Linguistic Studies. Amsterdam/ Philadelphia: John Benjamins. pp. 468-495.

Nencioni, Giovani. (1983). Di scritto e di parlato: Discorsi linguistici. Bologna: Zanichelli.
Raso, Tommaso. (2013). Fala e escrita: meio, canal, consequências pragmáticas e linguísticas. Domínios de Lingu@Gem, 7: $12-46$.

Raso, Tommaso \& Mello, Heliana. (2009). Parâmetros de compilação de um corpus oral: o caso do C-ORAL-BRASIL. Veredas, 2: 20-35.

Raso, Tommaso \& Mello, Heliana. (Orgs.). (2012). C-ORAL-BRASIL I: Corpus de referência do português brasileiro falado informal. Belo Horizonte: Editora UFMG.

Schwenter, Scott. (2005). The Pragmatics of Negation in Brazilian Portuguese. Lingua, 115: $1427-1456$

Sousa, Lilian. (2012). Sintaxe e Interpretação de Negativas Sentenciais no Português Brasileiro. ( $\mathrm{PhD}$ Thesis). Campinas: Universidade Estadual de Campinas.

't Hart, Johan; Collier, Rene \& Cohen, Antonie. (1990). A Perceptual Study on Intonation: An Experimental Approach to Speech Melody. Cambridge: CUP.

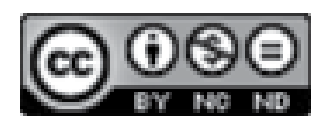

Este obra está bajo una licencia de Creative Commons

Reconocimiento-NoComercial-SinObraDerivada 4.0 Internacional 